\title{
SLAVIC WORLD: PROBLEMS OF POLITICAL AND CULTURAL RELATIONS
}

\author{
Yu. Uzlov 1
}

DOI: http://doi.org/10.15350/L_21/2/02

\section{Abstract}

To understand the essence of the issue, the article discusses the Slavic world as the main way of world development in the civilizational, cultural, geopolitical contexts, the system clusters and specific views.

Keywords: geopolitics, globalization, integration, modernization.

The World civilization to the beginning of the XXI century is the socioeconomic, technological and cultural organism, where the global problems facing humanity, determine the need to develop alternatives morally, socially, economically trajectories historical path of civilization, the reorientation of all kinds of human activity, a fundamental change in the mindset, going beyond the boundaries of technocratically oriented values and ideals.

The Socio-historical and cultural background of the emergence of the ideas of Slavic orientation originated in the lands of the Western Slavs, it was connected with the national liberation movement, one of the main elements of which was the idea of the necessity of unity and mutual assistance of the Slavic peoples. In Russia, interest in this movement emerged in the nineteenth century after the Napoleonic wars among the Russian intelligentsia.

The idea of Slavic actualized and played an important role in solving geopolitical problems during subsequent centuries: in 1941, became the basis of the organization of the Slavic Committee for mobilization of the Slavic peoples struggle against Nazi Germany; in 1946, he held the panSlavic Cathedral with the participation of representatives of the Slavic peoples; in 2005 IX pan-Slavic Congress announced the creation of the Union state of Belarus and Russia, which can be seen as a signal for the reconstruction of a multipolar world.

The Scientific-educational center of the North Caucasian Slavic" Kuban State University for several years studying the history of the Slavic world: Russian-Ukrainian relations; historical and ethno-cultural selection of the Slavic peoples; the Byzantine, Ottoman, Austro-Hungarian and German empires in the lives of southern and Western Slavs; the cultural heritage of the Slavic peoples; globalization and the Slavic world and other Kuban scientists have gained theoretical and empirical material on the conceptualization of the phenomenon of "Slavs", the study of the nature, content and dynamics of this image in the context of historical problems, international communications and the assessment of the impact on the processes of transmission of the image on the international arena.

The despite the importance of the research question, the literature does not contain a clear definition of the categories of "Slavic" and "Slavic world", there is a range of judgments and opinions, which is associated with a large set of concepts that bear these images.

${ }^{1}$ Yury Uzlov, Candidate of History Sciences, Associate Professor, Kuban State University, Russia. 
The social formation component of the global evolutionary process, just law divergence - the multiplicity and complexity of civilizations existing in continuous competition, mutual enrichment and addition: a viable, meet the conditions of habitat, replacing archaic, less able to adapt to changing conditions and innovations, as a result, synthesis and mutual penetration. Every civilization education is a complex evolving system, within which there is a continuous interaction between the various competing forms: industrial, spiritual and cultural, some elements are replaced by others.

Along with the variability of civilizational characteristics are conservative, defining features of ethnicity in a temporary space and builds possible patterns and trends of historical development. The wheel of history of the Slavic world was under the influence of climatic, geographical and geopolitical factors: a special position between East and West led to the cultural diversity of the Slavic peoples, the emergence of cultural phenomena.

This kind of cultural education belong to the category of "edge": a holistic community, formed at the boundaries of major civilizational formations for a long time and in the synthesis of the closely related and genetically distant cultures.

For such formations is characterized by such signs as polyethnicity, multi-religious reality, tolerance, religious tolerance, the capacity for cultural adaptation to the achievements and values of other cultures. These categories are fully applicable to the Slavs and Slavic world in General.

The weakness border-cultural formations is the incompleteness, failure of cultural synthesis that makes the formation of permanent transition, contradictory and unpredictable, they are particularly sensitive in the competitive struggle of civilizations.

Is it possible to consider the global problems as a threat to the Slavic world, bearing in mind that the events in Yugoslavia and Ukraine? Globalism and its adverse consequences cannot be associated with the twentieth century. Background of globalization were laid throughout the history of mankind. During the last centuries the peoples of the world was decided two issues: the achievement of national sovereignty and independence, freedom from external oppression and the establishment of democratic control over their own authority and its submission to the constitutional-legal norms.

A. Panarin, authoritative specialist we have studied the question $[1, \mathrm{p}$. 183-185] notes that the greatest illusion is that the process of global modernization is carried out in line with a single universal perspective. The inclusion of less-developed countries to a common standard developed countries in the process of collapsing.

M. Delyagin, according to [2, p. 185-186], globalization is the process of formation of a single global Finance information space on the basis of new, mostly computer technology, which qualitatively changes the nature of the business. This trend is fundamentally changing the nature of cooperation between developed and developing countries. Creative development of second first through direct investment gives way to destructive development by removing financial and intellectual resources. The gap between rich and poor countries on the basis of the action of such a system will not be reduced, and to increase swiftly.

The politically of globalization does not lead to integration and to the monopolist, to the formation of a unipolar world, with the center of this new 
world order is the financial capital of a number of developed countries under the auspices of the United States of America. The actors of globalization does not focus only on financial and economic manipulation. They are well aware that the most effective business is the transformation of human consciousness.

Traditionally it was considered that the main object of labour was a change of nature, now is the impact on human consciousness. Diverse types and forms of $\mathrm{PR}$ and advertising, unlike traditional marketing, not fit the product to the preferences of the people, but on the contrary, people to the product. Intensive development of the technology of manipulating the consciousness and behavior of people through various forms of propaganda, agitation national and cultural traditions, the imposition of others ' social norms and values.

Industrial civilization, creating a strong scientific and technical base, realizing the phenomenon of globalization of the economy, in their spiritual and value orientations remained at the level of primitive ideas of the society for mass-consumption.

Against this background, the problem of the Slavic world in the context of the system of the concept of global problems developed in the works: S. Artamovskogo, S. Ikonnikova, M. Kagan, A. Carmine; transnational forms of development formulated F. Cassedy, A. Panarin, M. Reshetnikov, A. Utkin, F. Fedorov, V. Shokhin.

V. Streletskaya [3, p. 330], author of articles on regional identity and cultural regionalism, European countries and Russia considers geocultural method as a mechanism of spatial self-organization of cultural complexes and their carriers, where the modern nation is a community of people United by culture and language, and not just the General area. As such, the boundaries of linguistic worlds are not the territories, as is commonly believed, but by the people and depending on what language the person speaks and thinks, is defined by its belonging to a cultural or civilizational space.

Geoculture as a method, has a unique opportunity and a way-difficulties in understanding and preserving images and traditions in the interpretation of historical images in its local space, it acts both as a process and as a result of development, that allows to consider it as an instrument of influence on the socio-cultural space.

With all the evidence of geoculture as a method, the semantic definition of this phenomenon is not, what causes the variability of the positions, quite non-uniform. There are situations when the object carries a double meaning: on the one hand, it represents a structural component of physical geography, on the other the sphere of material activity, a set of cultural images synthesized from a variety of natural, social, material and ideal elements that form a particular civilizational space.

Geoculture in the sphere of financial activity system is the concept of geopolitical and geo-economic problems, in such a plane, it races-is seen as a tradition of images, forming a civilizational space in which a set of personal schemes and which way the political design, based on the mobilization of certain cultural traits.

Geoculture can be represented as a system of stable relations and representations, which are formed on a certain area in the coexistence, weave, interaction, collision of different religions, cultural traditions and 
norms, values, deep psychological structures of perception and functioning: the preservation of these principles allows us to speak about the level of institutional development.

Thus, the geoculture takes the form of branding areas, incoming and outgoing for their civilizational framework, as such entities may be people, not included in the core of a particular civilization, including belonging to civilizational limitrophes.

Globalization, economic, political and cultural disparities complicate the possibility of building a modern geo-cultural space of the Slavic world without its unification. The axiological dimension geoculture represents a field where various schemes, influence each other, including on the dynamics of the space. Spatial schemes have certain semantic charge, helping to create a "force field", affecting nearby areas civilizational space. Geoculture as such is perceived as a system of regulatory bases of activity and its symbolic content.

A. Kolesnikov in the book "Philosophical comparative studies East - West" [4] attempted to present the history of the Slavs, as one of the specific areas of historical and philosophical direction. Geoculture may contain in addition to the economic structure, social relations between members of society, production, distribution, basic ideology - all components of this complex are interrelated, interact and form a single civilizational space.

The first project of globalization can be considered Hellenistic culture with the characteristics of universalism, which formed the basis of European civilization. The conquest by Alexander the great southwest Asia and Central Asia led to the creation of the Hellenistic world. Greek culture is basically prone to universalism was supposed to be shared around the world and interact with other cultures.

The Roman Empire was repeated cultural processes of the Hellenistic world: absorbed Hellenistic and created a global culture, brought to the West a culture of its own principles of morality, law, political consciousness, creating a unified state and legal organization; its characteristic features. Thanks to Roman civilization originated medieval West. Hellenistic civilization did not disappear, though, and ended its development as an organic whole. Hellenism is a unique phenomenon, given the common cultural values in all areas of spiritual and material human activity.

The Byzantine world has its own characteristics: the Greco-Roman and Eastern traditions have left their mark on public life, politics, religion, philosophy and culture. The Byzantine world, differing from the East and West, was at the same time link the two worlds. Byzantium world had a profound impact on the countries of medieval Europe, the distribution of which is from southern Italy and Sicily to the Balkans, the Crimea and the Caucasus.

As suggested by M. Isaev, Russia could finally merge with the Slavs not earlier than the twelfth century. The Russian Truth knows very well Rusina, bringing his Vikings (foreigner) and the Slav. This is a very characteristic feature in the Russian tradition. Typically, the sources of law barbarians reinforcing the legal status of different population groups and ethnic groups differently. Barbaric know the truth a similar differentiation between the peoples of the conquerors and, for example, by the Romans, who continue to live according to the right of the citizens. But what distinguishes the Russian legal as well as cultural-state civilization, of the total number barbaric and 
ancient images of Western culture, so this is a rejection of ethnic separateness as a principle of public life [5, p. 139].

East and West were spreading their ideology, culture, religion of life on a global scale. Rome embraced their influence almost all European countries. On the Balkan Peninsula and further North, for the lower over the Danube, as well as in the countries between the Black and Baltic seas, where he founded the Russian state, prevailed Byzantine civilization. The Nations that entered into the field of world-historical process, were distributed between global entities.

The Byzantine world was the kind of picture where geocultural and geopolitical space, being in close contact, led to the actual blending of the secular and spiritual power with the subsequent finding of the Universal ideas of the Eastern Roman Empire, which was confirmed in the letter of Patriarch Anthony Moscow Prince Vasily I (XIV). Byzantine space was largely cosmopolitan: lived on Athos Greek, Russian, Serbian, Romanian monks, and various scribes and translators of the sacred books in national languages has created a chain of effective cultural communication, which permeated the space, fed it and made it more dense.

The Byzantine world was heterogeneous: the periphery differed religious syncretism; the processes of acculturation took place rather slowly, as evidenced by the merge process and the interaction between pagan and orthodox traditions. Geocultural space Byzantium was, in fact, more pliable and flexible than geopolitical space. It continued to function in offline mode and after the fall of the Empire, although the main cultural ties were relegated by the Ottoman Empire to the North of the Balkans and in Russia, within Serbia, Romania and Moldova. This geocultural space had, in contrast to the geopolitical space, the structure, where the internal cultural boundaries was a series of transitional zones. The primary conduit of influence remained the Church. Important role in the formation of the Slavs as the world, played the Church Slavonic language, created for the needs of the cultural periphery, to a large extent contributed to the preservation and conservation of the Byzantine heritage.

Geographical diversity of individual regions, countries and continents makes it almost impossible perception of a single, main way of world development in its civilization, social, political and economic contexts. The way of the world development is a system of coordinated networks, or clusters targeted specific geographic megabrutal, including traditional ideas about the dynamics of geospatial development of certain human communities.

The Slavic world is focused on the convergence of the state and public initiatives Slavic peoples views on creating a life-affirming worldview and practical conduct of his life. The Slavs by nature itself free from the violence of nature, which the peoples of the Romano-Germanic century when the work of civilization could only move from one activity to another.

A. Hilferding [6], analyzing the reasons for loss to the nineteenth century. near the Slavic peoples of statehood, explained this lack of unity, the inability to resist external pressure. Slavs are insufficiently committed to the traditions, weakly rooted in the national soil, the result is easily adopt an alien culture are vulnerable to foreign influence and replace their own life foreign. History has subjected them to the domination of the public started West. Slav in the Czech Republic, in Moravia and Carinthia differs from the 
neighbor's German, Slovak, Magyar only language, dress, customs and peculiarities of his character. In public life he was identified with German or Magyar, his ideas about the state and state power, religion - not differ from those adopted in the Western world. Anyway, starting from the XII century Russia acts as the main ideological enemy of Europe.

I. Dusinsky, author of "The Geopolitics of Russia" [7, p. 72], notes that Russian encourages convergence with the Slavs congenital related sense, the consciousness of Slavic unity: the Slavic need Russia and more than Russia needs the Slavs. The future of the Slavic world lies in mutual harmony, unity and understanding common benefits, only political Union can once and for all to protect their land and to give impetus to the wide cultural development.

N. Danilevsky [8] believes that independence without unity weakens the Slavic people, making it the playfield foreign interests and intrigues, arming against each other. Unity without independence will deprive him of his liberty, the breadth and diversity of the inner life.

Our analysis of the sources shows that the majority of researchers of the Slavs consider the problem through the prism of the evolution of European Nations and inherent in this process phenomena, and by analogy transferred to other civilizations. This approach fits into the project system the concept of global problems.

Remaining numerous socio-cultural community, Slavic peoples gained largely different appearance, which confirms the presence in the modern world counter the dominant trends - globalization and national-cultural differentiation. The Slavic world was divided politically, economically, social forces explicitly slable districts.

Slavic countries, and the whole civilized world, has embarked on the road of modernization, which is not an easy choice but a requirement of the time, made a breakthrough in the modern developed economy, rely on new technologies, new socio-economic relations [9, p. 250].

Modernization of the XXI century involves the launch of a comprehensive socio-cultural process in which managerial and technological solutions are subject humanitarian purposes, and humanitarian objectives associated with economic objectives. The question is how to consider these factors in the context of global issues and how to work with them.

References:

[1] Panarin A. Globalization / Global studies. The encyclopedia. M., 2003.

[2] Delyagin M. Globalization / Global studies. The encyclopedia. M., 2003.

[3] Streletskaya N. The geospace in cultural geography. Humanities geography: scientific and cultural almanac. M., 2005.

[4] Kolesnikov A. Philosophical comparative studies: East-West. SPb., 2004.

[5] Isaev M. lectures on the history of Russian law and the state. Vol. 1. M.: Moscow State University, 1996.

[6] Hilferding A. Russia and Slavdom. M.: 2009.

[7] Dusinsky I. Geopolitics of Russia. M.: 2003.

[8] Danilevsky N. Russia and Europe. M.: 1991.

[9] Uzlov Y. Slavic world in the context of geocultural space. The Slavic world and Russia. Krasnodar, 2014. 